\title{
Development of cost efficient solar receiver tube with a novel tandem absorber system
}

\author{
M. Shiva Prasad, K. Chandra Sekhar Reddy and S. Sakthivel*
}

Centre for Solar Energy Materials, International Advanced Research Centre for Powder Metallurgy and New materials, Balapur PO, Hyderabad-500 005, India.

\begin{abstract}
New single layer, double layer and triple layer absorber tandems were designed and developed for high performance Organic Ranking Cycle (ORC) based solar thermal applications. A Cr-Mn-Fe composite oxide based absorber layer is devolved by controlled chemical oxidation and designed to have a nanoporous structure. It is covered with double antireflective layers a $\mathrm{ZrO}_{2}-\mathrm{SiO}_{2}$ nanocomposite layer developed by the sol-gel route and a porous $\mathrm{SiO}_{2}$ layer obtained from $\mathrm{SiO}_{2}$ nanoparticle suspension. Double and triple layer tandem absorbers were developed by a combination of chemical, sol-gel and nanoparticle suspension methods. By varying process parameters like duration, temperature and withdrawal speed, different combinations of $\mathrm{Cr}-\mathrm{Mn}-\mathrm{Fe}$ oxides $/ \mathrm{ZrO}_{2}-\mathrm{SiO}_{2}$ double layer tandem and $\mathrm{Cr}-\mathrm{Mn}$-Fe oxides $/ \mathrm{ZrO}_{2}-\mathrm{SiO}_{2} / \mathrm{SiO}_{2}$ triple layer tandem composite absorber layers with varying refractive indices were developed on an economical variety of SS substrate. The optimized thickness of the absorber layer along with the antireflective layers shown a high absorptance $(\alpha=94.9)$ and low warm emittance $\left(\varepsilon=0.122\right.$ at $\left.300^{\circ} \mathrm{C}\right)$. More specifically, this novel double layer tandem coating has excellent optical properties along with high corrosion resistance (withstands $>200 \mathrm{~h}$ in salt spray test). It has good thermal stability in an open air atmosphere and is well suited for low and medium temperature solar thermal applications.
\end{abstract}

Keywords: Tandem absorber layer, nanoporous, $\mathrm{Cr}-\mathrm{Mn}$-Fe composite oxide, $\mathrm{ZrO}_{2}-\mathrm{SiO}_{2}, \mathrm{SiO}_{2}$ nanoparticle layer, antireflective layer

* To whom correspondence should be addressed.

Fax: $+91-40-24442699$

E-mail: ssakthivel@arci.res.in 


\section{Introduction}

Solar thermal power represents a leading approach in solar energy conversion, which is used in concentrating solar power (CSP) systems. It is expected that by 2050, with appropriate support, CSP will provide more than $10 \%$ of global electricity [1]. The common base of all CSP technologies are the solar receivers play an important role in heat generation for electrical power production. In principle the absorber coatings in the collector system convert photon energy of sunlight to thermal energy which is then converted to electrical energy [2-6]. Absorber surfaces are typically classified as selective and non-selective depending on the absorptance to emittance ratio [7]. Conventionally, most of the selective absorber coatings preferred for concentrated solar collector applications are developed by the expensive Physical Vapour Deposition route, particularly by magnetron sputtering [719]. Currently, the entire CSP program is working to reduce the cost of solar thermal power technology. One of the approaches is to operate the CSP system using cost effective solar receivers in open air atmosphere conditions instead of using expensive evacuated solar receivers. To accomplish this, efficient selective receivers that have optical properties and high stability against corrosion, in addition to enhanced thermal properties are needed. For efficient photo thermal conversion, solar receivers must have high solar absorptance $(\alpha)$ in an active solar region $(300-2500 \mathrm{~nm})$ and a low thermal emittance $(\varepsilon)$ in the IR radiation wavelength range $(3-25 \mu \mathrm{m})$ at an optional operational temperature. Most of the current coatings do not have stability against corrosion and temperature and this is the main problem faced while operating the receivers in an open atmosphere [7, 20]. Moreover, the coatings need to be stable in air in case the vacuum is breached.

Solar selective coatings can be improved to have high optical properties, stability against air at operational temperature, long environmental stability, high scratch and abrasion resistance and high mechanical integrity. Coatings prepared by an economic process, e.g. electrochemical deposition technique [21-24], thermal oxidation [25-29], chemical oxidation [30-31], sol-gel process $[20,32,33]$ etc. on easily available substrates (e.g. stainless steel) with a combination of above mentioned properties would be a great choice for power generation by a CSP system. Nowadays, solar absorptance of most common high-quality commercial absorbers is about $95 \%$ and the thermal emittance is 
$<10 \%$ at the process temperature range of $100-400^{\circ} \mathrm{C}$. The techniques that have been attempted so far for cost efficient solar absorber coatings have faced many challenges to produce coatings with high optical efficiency as well as high environmental and thermal stability.

Very few studies have reported high optical efficiency with temperature and corrosion stabilities for solar absorber coatings made by sol-gel process. For example, such a coating was prepared from polysiloxane as a binder and $\mathrm{Co}_{3} \mathrm{O}_{4}$ as a spinel pigment on 304 stainless steel by spin-coating [34]. Spectrally selective absorber coatings were prepared by spin-coating of nickel nanoparticles embedded in alumina and coated with an antireflective layer made of silica, alumina, or silica-titania mixture [32]. Vince et al. [35] reported doping of $\mathrm{CuCoMnOx}$ by $\mathrm{Ti}$ in a polysiloxane resin. The films were used in order to increase the weather resistance and showed absorptance of $0.86-0.91$ and emittance below 0.036 . Tulchinsky et al. [20] reported the thermal chemical reaction between a titania sol-gel precursor with a copper manganese spinel to form a new material, $\mathrm{Cu}_{0.44} \mathrm{Ti}_{0.44}$ $\mathrm{Mn}_{0.84} \mathrm{Fe}_{0.28} \mathrm{O}_{3}$, having a bixbyite structure. Although solar absorptance of the films was reported around $97.4 \%$, there was no information about thermal emittance of the film. Chao-Ching Chang [36] reported poly (urethane)-based solar absorber coatings containing copper chloride and nano gold composite synthesised by solution-chemical technique. The solar absorptance and thermal emittance of this coating were shown to be only around 0.846 and 0.09 , respectively. Copper-cobalt oxide thin films deposited on aluminium substrates via a facile sol-gel dip-coating method showed solar absorptance of around 83.4. [37]. A higher value of solar absorptance and better stability is needed for the films to be suitable for concentrated solar thermal power application.

Martin et al. [38] produced multi-layered chrome free black selective surfaces for solar thermal energy conversion by a low-cost sol-gel dip-coating method. The optical properties of solar absorptance and thermal emissivity at $100^{\circ} \mathrm{C}$ of the $\mathrm{Cu}-\mathrm{Co}-\mathrm{Mn}-\mathrm{Si}-\mathrm{O}$ based nano crystalline thin films were shown to be around 0.95 and 0.12 . The coatings were stable up to a maximum of $360^{\circ} \mathrm{C}$ in air which surpasses that of the conventional robust black chrome coatings existing in the market. But there was no report on the weather stability of the novel multilayer absorber coating. 
For CSP application, coatings are required on a large area and development of solar receiver tubes with all the properties like high solar absorptance, low thermal emissivity, high weather and thermal stabilities by an economic way is the main objective in order to reduce the cost of solar electricity production. In view of the above, herein, we report novel double and triple layer tandem absorber systems developed by a combination of chemical oxidation, sol-gel and nanoparticle suspension processes for high performance Organic Ranking Cycle (ORC) based solar thermal system operating at the range of $200-300^{\circ} \mathrm{C}$ having excellent optical properties along with high corrosion resistance and good thermal stability in an open air atmosphere and their optical and structural characterizations.

\section{Experimental Section}

\subsection{Chemicals used for the preparation of single, double and triple layer absorber tandems:}

All chemicals in this work were purchased commercially and used without any further purification. Sodium dichromate dihydrate (99\%), isopropylalcohol (99\%), sulphuric acid (98\%) were purchased from Merck. Zirconium n-propoxide (70\% in n-propanol), 3glycidoxypropyl trimethoxisilane (GPTS, 97\%) and 2-isopropoxyethanol (99\%) were obtained from Alfa Aesar. $\mathrm{SiO}_{2}$ nanoparticle suspension (Levasil 200-E, 20\%) was obtained from Obermeier, Germany.

\subsection{Sample preparation}

In a preliminary step of the process, the stainless steel (SS) tubes are cleaned by ultra-sonication with a mild detergent solution followed by rinsing with tap water and then deionised water. They are wiped with a soft cotton cloth dipped in an organic solvent, preferably isopropyl alcohol (IPA), to make it free of any external impurities adhering to the surface. The cleaned substrates are then dried either by an air drier or by keeping them at $100^{\circ} \mathrm{C}$ for 5-10 $\mathrm{min}$ in an air oven. The dimensions of SS tube used for this study were 500 $\mathrm{mm} \times 25 \mathrm{~mm} \times 1.25 \mathrm{~mm}$ (Length $\times$ Width $\times$ Thickness). 


\subsection{Development of nanoporous composite single absorber layer on SS 202 tubes}

The thin nanoporous $\mathrm{Cr}-\mathrm{Fe}-\mathrm{Mn}$ composite oxide absorbing layers were developed on smooth, highly specular reflecting mirror of stainless steel substrates by a controlled chemical oxidation process. The special but economical stainless steel tube (SS-202) had a composition of C: $0.15, \mathrm{Mn}: 7.5-10, \mathrm{P}: 0.06$, S: 0.03, Si: 1.00, Cr: 17-19 and Ni: 4-6; and Fe: 69-73 wt\%. A precise temperature controllable chemical bath reactor was used with optimum conditions of molar concentration of chromium salt, acid and water ratio, temperature and process duration. $1 \mathrm{M}$ sodium dichromate salt dispersed in a mixture of sulphuric acid and water (3:5) was used for the development of nanoporous morphological structure absorber layer. The detailed preparation procedure of the absorber layer as described elsewhere [39]. In a preliminary step of the process, the SS tube sample is cleaned with a mild detergent solution and rinsed with tap water followed by deionised water and finally wiped with a soft cotton cloth using with an organic solvent, preferably isopropyl alcohol (IPA), to make it free of any external impurities adhering on the surface. The cleaned substrate is then dried either by an air drier for $2-5 \mathrm{~min}$ or by placing at $100^{\circ} \mathrm{C}$ for $5-10 \mathrm{~min}$ in an air-oven.

The cleaned substrates were immersed into the acid bath for chemical oxidation in a temperature range of $80-90^{\circ} \mathrm{C}$ for $20-30 \mathrm{~min}$. The acid mixture for the development of selective absorber layer consisted of $15-30 \mathrm{wt}$. \% Na/K dichromate salt, 37.5-53 wt. \% deionised water and 21-34 wt.\% conc. sulphuric acid. The ideal ratio of the three components was 23.09:48.43:28.48 (wt\%). During the chemical oxidation process, the metal atoms on the surface of substrates are partially oxidized by the acid mixture to obtain a type of nanoporous composite oxide layer. The SS tubes turned to grey colour with a glassy appearance after the chemical process. After that the SS tube was washed immediately with tap and distilled water and finally wiped with a soft cotton cloth using an organic solvent, preferably IPA. The tube was then dried by an air drier for 2-5 min.

\subsection{Development of double layer absorber tandem}

After deposition of nanoporous Cr-Fe-Mn composite oxide absorber layer by the above mentioned chemical oxidation process, an antireflective layer with corrosion protection 
property comprising $\mathrm{ZrO}_{2}-\mathrm{SiO}_{2}$ composite, was deposited by dip coating process using a composite sol obtained by mixing zirconium n-propoxide and 3-glycidoxy propyltrimethoxysilane compound in a mixture of isopropyl alcohol and isopropoxyethanol to obtain a stable sol. For $\mathrm{ZrO}_{2}-\mathrm{SiO}_{2}$ nanocomposite sol preparation, the specific amounts of zirconium n-propoxide and 3-glycidoxypropyltrimethoxysilane were dispersed in a solvent mixture of isopropyl alcohol and isopropoxy ethanol (70:30) for 24h. The details of the preparation procedure are described elsewhere [39]. The solution was allowed to stand at room temperature for an hour and finally used for the coatings. The final composition of the coating sol for this layer was in the ratio of $\mathrm{Zr}$ (n-Pro): IPA: IPE: GPTS = 6.94:78.52:12.94:1.60 (wt\%). No binder/additive was used for the coating. As per LandauLevich equation the coating thickness is proportional to the withdrawal speed of coating sol [40]. Hence, increase in withdrawal speed during dip coating resulted in increase of coating thickness and in turn the packing density. In order to obtain highly optical enhancing thin films, the coating speed and curing temperature were varied from 2 to $5 \mathrm{~mm} \mathrm{se}^{-1} \mathrm{c}$ and 100 $300^{\circ} \mathrm{C}$ respectively.

\subsection{Development of triple layer absorber tandem}

To develop a triple layer absorber tandem a second antireflective layer with nanoporous structures were deposited by dip coating process, the top of the double absorber tandem using a commercial $\mathrm{SiO}_{2}$ nanoparticle suspension. The suspension comprised spherical size $\mathrm{SiO}_{2}$ nanoparticles having size in the range of 11 to $36 \mathrm{~nm}$ and an average particle size of about $15 \mathrm{~nm}$.

\subsection{Characterization methods}

\subsubsection{Optical characterization:}

Optical properties of the nonporous single absorber layer, the double and triple layer absorber tandems were measured after completion of drying and curing process. The nanoporous absorber layer developed by chemical oxidation was dried in hot air oven at $100^{\circ} \mathrm{C}$ for $15 \mathrm{~min}$. This was followed by deposition of $2^{\text {nd }}$ layer by dip coating process and curing at $300^{\circ} \mathrm{C}$ for $1 \mathrm{hr}$. After cooling, $3^{\text {rd }}$ layer was applied similar to the $2^{\text {nd }}$ layer and cured at $300^{\circ} \mathrm{C}$ for $1 \mathrm{hr}$. The diffuse reflection spectral measurements in the UV/ Vis /near-IR region 
were carried out by a Cary 5000 spectrophotometer equipped with a standard integrating sphere $(110 \mathrm{~mm}$ dia) at room temperature in the spectral interval of $0.3-2.5 \mu \mathrm{m}$ with a scanning speed of $1200 \mathrm{~nm} \mathrm{~min}{ }^{-1}$. Normal emittance measurements in the infrared wavelength region were carried out by a Bruker Vertex 70 FTIR (Fourier Transform Infrared) spectrophotometer equipped with a standard integrating sphere using an evaporated gold mirror as a reference plate. All the measurements were done in the spectral interval of 2.5$25 \mu \mathrm{m}$ with a scanning velocity of $2.5 \mathrm{kHz}$.

The normal absorptance $(\alpha)$ and emittance $(\varepsilon)$ values were calculated using standard equations as described in literature [41]. The solar absorptance, $\alpha_{\text {sol }}$ of the sample was calculated as a weighted fraction between absorbed radiation and incoming solar radiation using an AM 1.5 spectrum. The direct normal solar irradiance, I, is defined according to the ISO standard 9845-1 (1992) where an air mass of 1.5 is used [41].

\subsubsection{Thermal loss (thermal emissivity) measurement with respect to the black body:}

The thermal emittances of coated samples as well as black body furnace were measured at different temperatures such as $100^{\circ} \mathrm{C}, 150^{\circ} \mathrm{C}, 200^{\circ} \mathrm{C}, 250^{\circ} \mathrm{C}$, and $300^{\circ} \mathrm{C}$. Finally, the thermal loss (thermal emissivity) value was estimated by taking the ratio of thermal emittance of coated sample and the black body at a given temperature [42]. In the other reported works, thermal loss of a sample is generally calculated using theoretical black body distribution instead of measured blackbody emittance [41, 43]. FTIR spectrometer equipped with the standard accessories of black body furnace with a high temperature and high pressure (HTHP) cell (sample compartment) supplied by Bruker optic GmbH was used for the measurement of thermal radiation emittance. The schematic of the equipment with all the thermal emittance measurement accessories is represented in Fig. 1. For thermal emissivity calculation, initially the thermal radiation emittance spectra $(2.5-25 \mu \mathrm{m})$ of both black body and the sample coated with selective absorber layer were measured one after another by heating black body furnace and coated sample in the sample compartment at temperature range of 100 to $300^{\circ} \mathrm{C}$. Finally, the thermal emissivity was calculated by using the formula, $\varepsilon_{\mathrm{t}}=$ sample emittance radiation/black body emittance radiation generated at the same temperature from $2.5-25 \mu \mathrm{m}$. 


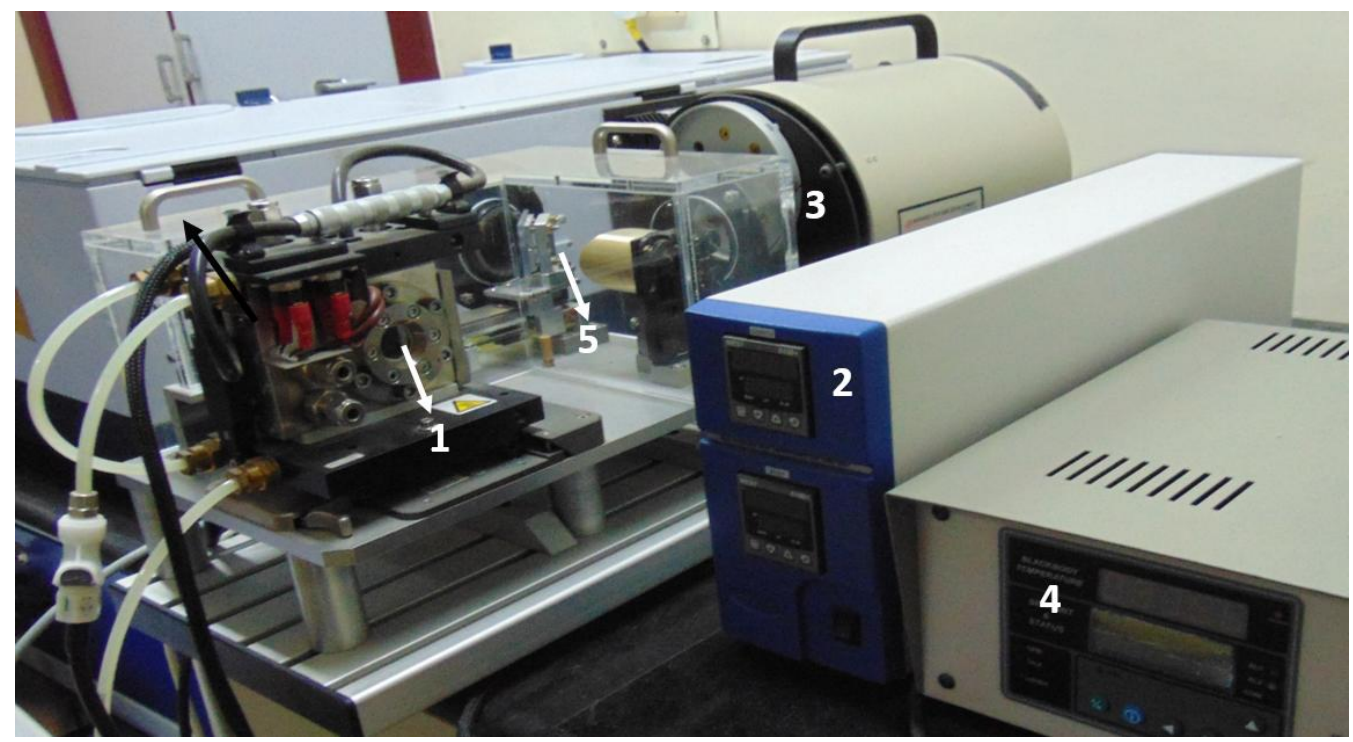

Figure 1 A digital image of FT-IR connected with thermal emissivity accessories: 1) High temperature \& high pressure (HTHP) cell for thermal emittance of absorber samples measurement; 2) Temperature controlled for HTHP; 3) Black body furnace (BBF) for thermal emittance of black body; 4) Temperature controller for BBP; 5) Automated switching mirror

\subsubsection{Structural and other physical-chemical characterisations:}

X-ray diffraction pattern was recorded by using Bruker AX D8 XRD equipment having $\mathrm{Cu} \mathrm{K} \mathrm{K}_{\alpha} \mathrm{X}$-ray source. The scan was taken in the range $0-100^{\circ}$ with an increase of $0.01^{\circ}$ at a duration of 2 step $^{-1}$. Surface morphology of absorber layers was studied by field emission scanning electron microscopy, FE-SEM (Hitachi S4300SE/N) operated at $20 \mathrm{kV}$.

Coating thickness and refractive index of the composite layers were measured using a spectroscopic ellipsometer (M-2000V, J. A. Woollam Co. Inc.) in the wavelength range of 350-1000 $\mathrm{nm}$. The chemical composition and oxidation state of the nanoporous absorber layer were analyzed by X-ray photoelectron spectrometer (Omicron-ESCA+) equipped with Al Ka anode and Raman spectrophotometer (HR 800, Horiba Jobin-Yvon, France).

\section{Results and Discussion}

\subsection{Design and fabrication of cost efficient single layer, double and triple layer tandem absorber systems}

The schematic diagram of the nanoporous $\mathrm{Cr}$-Fe-Mn composite oxide layer (single layer), the nanoporous $\mathrm{Cr}$-Fe-Mn composite oxide layer $/ \mathrm{ZrO}_{2}-\mathrm{SiO}_{2}$ double layer tandem absorber and the nanoporous $\mathrm{Cr}-\mathrm{Fe}-\mathrm{Mn}$ composite oxide $/ \mathrm{ZrO}_{2}-\mathrm{SiO}_{2} / \mathrm{SiO}_{2}$ nanoparticle triple layer tandem absorber is shown in Fig. 2. An absorber-reflector tandem absorber concept 
was used to develop the absorber on SS substrates, wherein the $\mathrm{Cr}$-Fe-Mn nanoporous composite oxide layer and smooth SS surface (surface roughness approximately $<1$ micron) act as base absorber layer and infrared reflector respectively in all the three absorber systems. It is well known that the optical properties of transition metal based coatings can be tailored by controlling the stoichiometry, which effect the density of free electrons in the $\mathrm{d}$ band [44]. Based on this concept, the first absorber layer Cr-Fe-Mn composite oxide was designed to have higher amount of $\mathrm{Cr}$ oxide content than the $\mathrm{Fe}$ and $\mathrm{Mn}$ oxides in order to achieve high selective property with a suitable refractive index that compatible with $\mathrm{ZrO}_{2}-$ $\mathrm{SiO}_{2}$ nanocomposite and $\mathrm{SiO}_{2}$ nanoparticle layers for further optical enhancement and corrosion protection.

A base absorber layer of $\mathrm{Cr}-\mathrm{Fe}-\mathrm{Ni}$ nanoporous composite oxide layer with nanoporous structure (195 $\mathrm{nm}$ average pore diameter) was developed by controlled chemical oxidation process for designing of single, double and triple layer tandem absorber systems using optimum process parameters like a process temperature, $80-90^{\circ} \mathrm{C}$, process duration, 9-17 min and an optimum concentration of acid mixture, 1M sodium dichromate salt dispersed in a mixture of sulphuric acid and water (3:5), respectively. Followed by the deposition of $\mathrm{Cr}$-Fe-Ni nanoporous composite oxide layer by the controlled chemical oxidation, the antireflective layers of $\mathrm{ZrO}_{2}-\mathrm{SiO}_{2}$ nanocomposite sol-gel layer and $\mathrm{SiO}_{2}$ nanoparticle layer are deposited one after another by sol-gel dip coating process. The first and second antireflective layers were cured at $100^{\circ} \mathrm{C}$ and $300^{\circ} \mathrm{C}$ respectively for 2 hours by heating at a rate of $10^{\circ} \mathrm{C} / \mathrm{min}$.

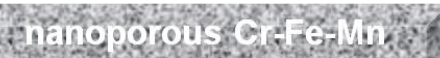

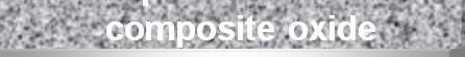
Polished SS tube
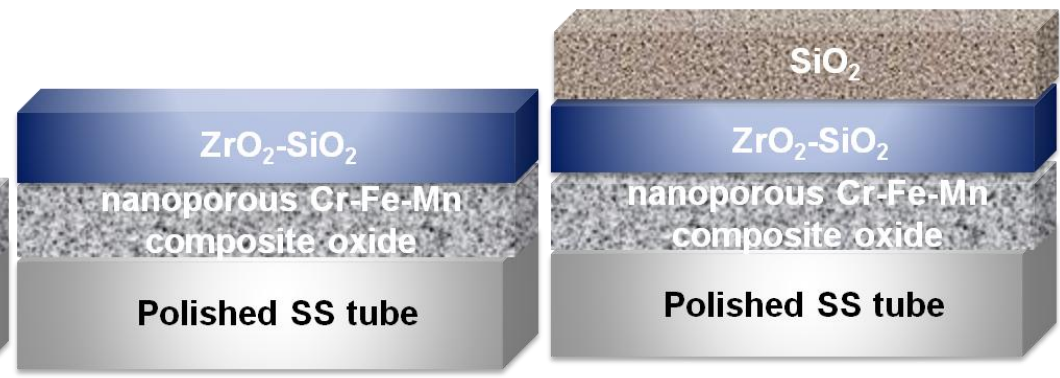

Figure 2. Schematic diagram of the single layer, double layer absorber tandem and triple layers absorber tandem deposited on stainless steel tube 


\subsection{Field Emission Scanning Electron Microscope (FE-SEM):}

The FE-SEM surface morphology images of the single layer as well as the tandem layer absorber coatings are as shown in Figure 3. It can be observed that the surface morphology of $\mathrm{Cr}$-Fe-Mn composite oxide absorber layer (single layer) on SS-202 polished surface (Fig. 3a) has a nanoporous morphological structure with an estimated pore diameter in the range of 174 to $363 \mathrm{~nm}$. Cr, Fe and $\mathrm{Mn}$ were the predominant metal atoms involved in the oxidation process. The surface morphology of $\mathrm{ZrO}_{2}-\mathrm{SiO}_{2}$ (double layer tandem (Fig. 3b)) shows that the layer is uniform without any cracks and pinholes. However the surface morphology of $\mathrm{SiO}_{2}$ nanoparticle layer (triple layer tandem (Fig. 3c)) comprises a very fine distribution of nanopores $(<10 \mathrm{~nm})$ and voids generated due to particle shrinkage during drying and curing processes. Analysis by EDS was done on the bare substrate and nanoporous absorber layer deposited substrate (Table 1) and it can be observed that nanoporous layer deposited contain of oxygen indicating an oxide layer formation on the substrate.
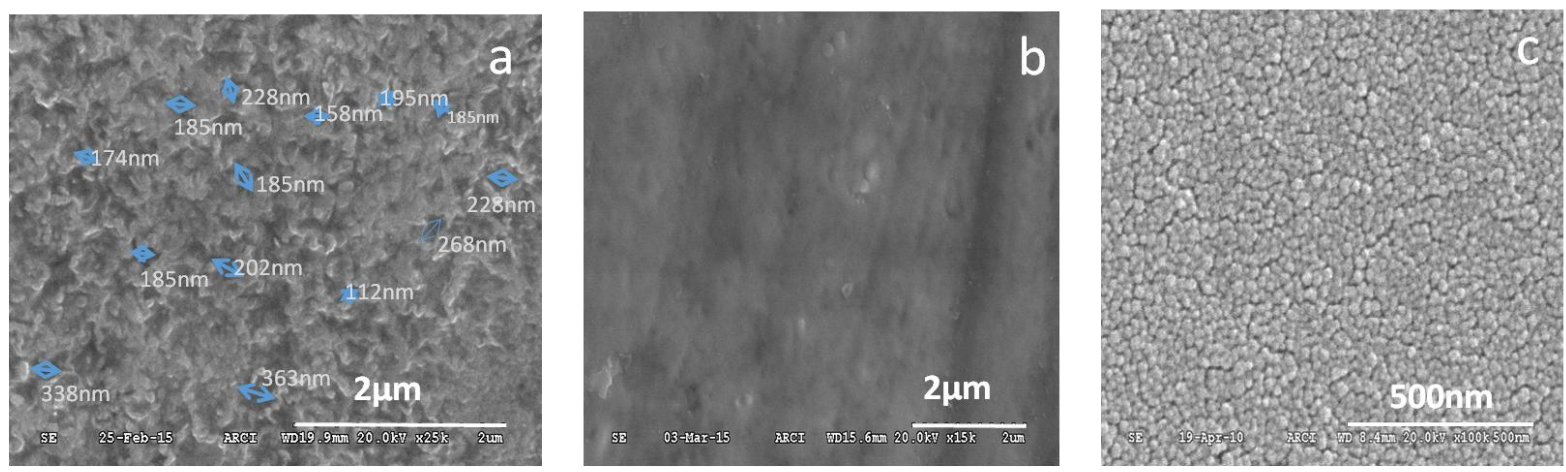

Figure 3. (a) FE-SEM surface morphology of single layer; (b) $\mathrm{Cr}$-Fe-Mn nanoporous composite oxide layer after covering with $\mathrm{ZrO}_{2}-\mathrm{SiO}_{2}$ composite oxide sol-gel layer (double layer tandem); (c) $\mathrm{Cr}$-Fe-Mn nanoporous composite oxide layer after covering with $\mathrm{ZrO}_{2}-\mathrm{SiO}_{2}$ composite oxide sol-gel layer followed by $\mathrm{SiO}_{2}$ nanoparticle layer (triple layer tandem).

Table 1: EDX data of bare and nanoporous absorber layer deposited SS substrate

\begin{tabular}{|c|c|c|c|c|c|c|c|}
\hline Substrate & $\% \mathrm{Fe}$ & $\% \mathrm{Mn}$ & $\% \mathrm{Cr}$ & $\% \mathrm{Si}$ & $\% \mathrm{Ni}$ & $\% \mathrm{~S}$ & $\% \mathrm{O}$ \\
\hline Bare SS 202 & 73.60 & 10.83 & 15.50 & - & 1.04 & - & - \\
\hline SS-202 with nanoporous layer & 43.97 & 6.09 & 15.73 & 1.41 & 1.28 & 0.88 & 29.4 \\
\hline
\end{tabular}




\subsection{Transmission electron microscopy (TEM):}
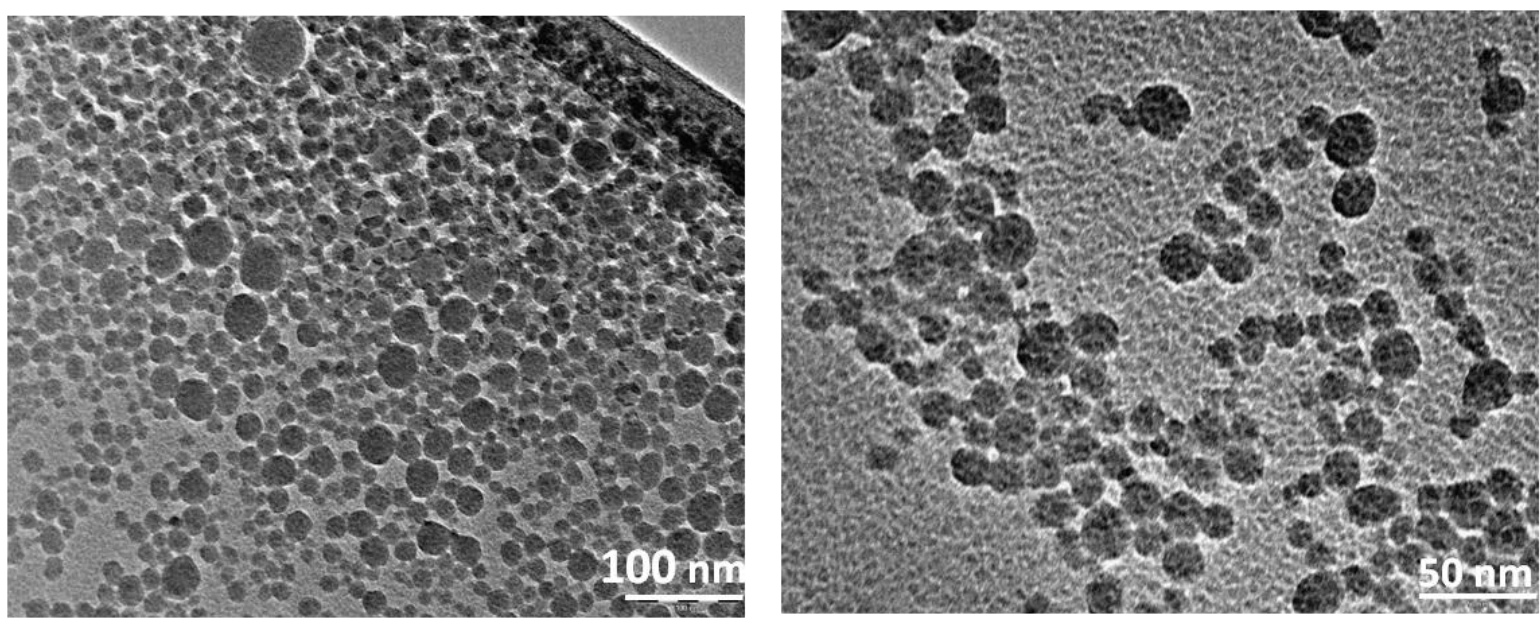

Figure 4. TEM surface morphology of $\mathrm{SiO}_{2}$ nanoparticles used for $\mathrm{SiO}_{2}$ nanoparticle layer for triple layers absorber tandem

The TEM particle morphology image of $\mathrm{SiO}_{2}$ nanoparticles is represented in Figure 4. According to TEM analysis, the particles are spherical in shape, the paricle size ranges between 11-36 $\mathrm{nm}$ and average particle size was estimated around $15 \mathrm{~nm}$.

\subsection{X-Ray Diffraction (XRD) results:}

The results of the incident angle XRD studies for the nanoporous $\mathrm{Cr}$-Fe-Mn composite oxide developed using optimized conditions are shown in Fig. 5 and are compared with the diffraction peaks of bare SS-202 sample. The peaks observed in the bare substrate indicate an austenitic type (FCC) steel. It is surprisingly noted that the XRD patterns of chemically oxidized samples are quite similar to the bare substrate. The reason could be that a high content of iron (69-73\%) in the substrate dominated other components like chromium, manganese and nickel during analysis. Moreover, the atomic numbers of chromium, nickel, and manganese are very close to metallic iron. From XRD analysis it is quite difficult to distinguish if the element is in low concentration or the layer thickness is in nano range. 


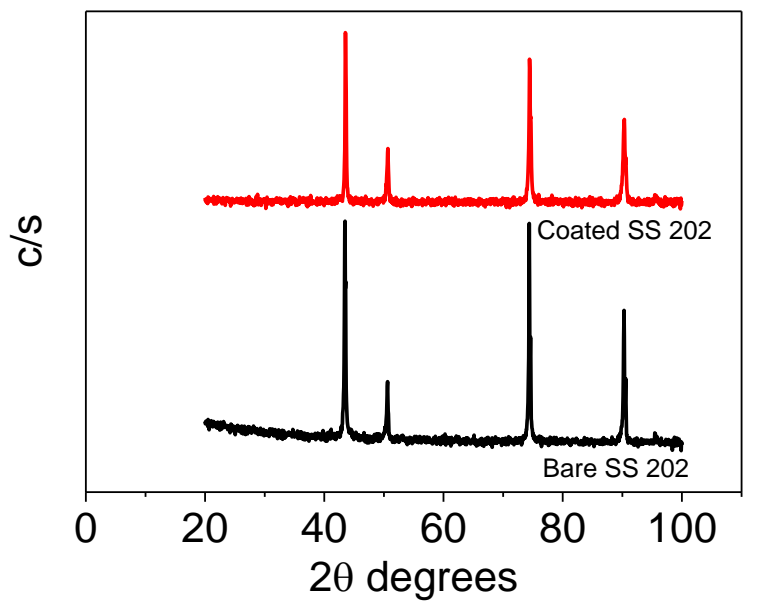

Figure 5. XRD patterns of both bare and nanoporous $\mathrm{Cr}$-Fe-Mn composite oxide absorber layer developed on SS-202 polished plate

\subsection{X-Ray photoelectron spectroscopy (XPS) results:}

The coating compositions of the nanoporous $\mathrm{Cr}$-Fe-Mn absorber layer and the oxidation states of each element were clearly confirmed by XPS. Fig. 6 (a-d) shows the high resolution core level X-ray photoelectron spectra (XPS) for an absorber layer developed on SS 202 polished surface. The Cr spectrum (Figure. 6(a)) consist of 3 primary peaks at 575.95, 577.54, $573.9 \mathrm{eV}$ which originate from $\mathrm{Cr} 2 \mathrm{p}^{3 / 2}$ electrons in $\mathrm{Cr}_{2} \mathrm{O}_{3}, \mathrm{CrO}_{3}$ and $\mathrm{Cr}$, respectively [45-47]. The Fe $2 p$ spectrum (Fig. 6(b)) exhibited three peaks centered at 707.32, 709.88 and $706.49 \mathrm{eV}$ which correspond to $\mathrm{Fe} 2 \mathrm{p}^{3 / 2}$ of $\mathrm{FeO}, \mathrm{Fe}_{2} \mathrm{O}_{3}$, and $\mathrm{Fe}$, respectively $[20,42]$. The Mn 2p spectrum (Fig. 6(c)) exhibited 3 peaks centred at $642.89,640.69$ and $638.37 \mathrm{eV}$ which correspond to $\mathrm{Mn} 2 \mathrm{p}^{3 / 2}$ of $\mathrm{MnO}_{2}, \mathrm{MnO}$ and $\mathrm{Mn}$, respectively $[20,41]$. The 1 s spectrum of oxygen (Fig. $6(\mathrm{~d})$ ) of the absorber coating ( $\mathrm{Cr}$-Fe-Mn oxide layer) the presence of two primary peaks cantered at 530.15, $531.21 \mathrm{eV}$, which correspond to oxides $\mathrm{Fe}, \mathrm{Mn}$ and $\mathrm{Cr}$. From this result, it is clear that the nature of composite absorber layers formed by the controlled chemical oxidation method may depend upon the process conditions. According to XPS analysis, the surface composition of the absorber layers in atomic percentage was in the ratio of 15.11: 21.52: 1.89: 61.48 (Cr: Fe: $\mathrm{Mn}: 0$ ). 

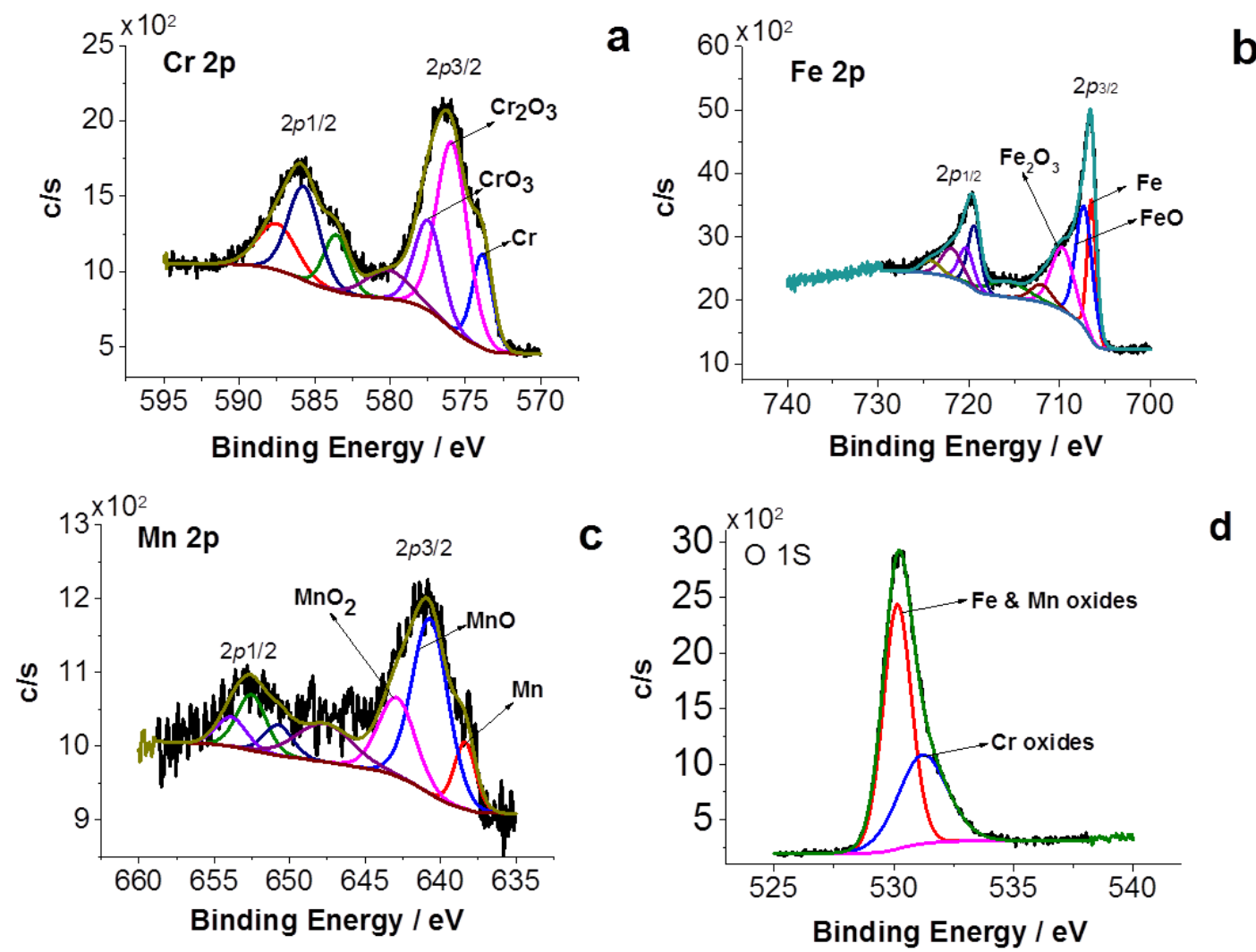

Figure 6. X-ray photon electron spectra of absorber layer developed on SS 202 surface: core level XPS spectra of: (a) Cr2p, (b) Fe2p, (c) Mn2p and (d) O 1s

\subsection{Solar absorptance of single and tandem absorber systems:}

Single absorber layers were developed by varying the process duration (the immersion time of SS Substrate in chromic acid at an optimized temperature, $90^{\circ} \mathrm{C}$ ) while keeping other process parameters like process temperature, acid and water ratio and sodium dichromate salt concentration constant. The optimum conditions of process temperature, acid and water ratio and sodium dichromate salt concentration used were $90^{\circ} \mathrm{C}, 3: 5$ and $1 \mathrm{M}$, respectively. The spectrum of nanoporous absorber layer developed at this condition is represented in Figure 7a. It shows slightly higher reflectance in the solar wavelength range and the absorption from $300-2500 \mathrm{~nm}$ is not as much as required. Moreover, it is noted that solar absorptance increases with increasing of process duration due to increase of porosity in the layer. As mentioned our earlier report [42], if the layer having nanoporous structure, it will reduce the scattering of light and in turns absorb more light. Similarly, it observed an optical enhancement for nanoporous absorber layer generated by chemical oxidation process. The absorptance of the sample, optimized by the process duration, the maximum solar absorptance of $86.6+0.1$ was reached; it's fully fits for 
a single absorber system. However, the solar absorptance for bare substrate (SS 202) only $42 \%$ was observed from $300-2500 \mathrm{~nm}$.

The, next step consisted of enhancing the solar absorptance of the single absorber coating by adding an anti-reflection layer with protective property on the top of the nanoporous absorber layer. The anti-reflection layers used was generated from $\mathrm{ZrO}_{2}-\mathrm{SiO}_{2}$ nanocomposite coating sol. The anti-reflection layer with corrosion protective property deposited with an optimum withdrawal speed of $4 \mathrm{~mm} \mathrm{sec}{ }^{-1}$ on all the absorber layers generated by various process durations followed by curing at $300^{\circ} \mathrm{C}$ for $2 \mathrm{~h}$ exhibits a maximum solar absorptance of $94.9 \%$ (Figure $7 \mathrm{~b}$ ).

For further optical enhancement, a triple layer tandem absorber design (graded index coating composited of three distinct layers) was then designed. After the development of nanoporous $\mathrm{Cr}-\mathrm{Mn}$-Fe composite absorber layers by the above described controlled chemical oxidation process with varying process duration, an antireflective layer $\left(\mathrm{ZrO}_{2}-\mathrm{SiO}_{2}\right.$ sol-gel composite layer) with corrosion protective property was deposited further by sol-gel dip coating process using a constant withdrawal speed of $4 \mathrm{~mm} \mathrm{sec}{ }^{-1}$. After completion of curing process, another antireflective layer $\left(2^{\text {nd }}\right.$ layer $)$ comprising of spherical size $\mathrm{SiO}_{2}$ nanoparticles having size in the range about 11 to $36 \mathrm{~nm}$ and an average particle size about $15 \mathrm{~nm}$, which is further deposited over the $1^{\text {st }}$ antireflective layer by the same dip coating process using a constant withdrawal speed of $3 \mathrm{~mm} \mathrm{sec}{ }^{-1}$. After deposition, the coated tube was transferred to a hot air oven and subjected to curing at $300^{\circ} \mathrm{C}$ for $2 \mathrm{~h}$ with $10^{\circ} \mathrm{C} / \mathrm{min}$ heating rate to obtain a perfect tandem system with graded refractive index. It is expected that an intermediate layer favours the light penetration and absorption, leading to a maximum solar absorption of $>95 \%$. However, the triple layer tandem represented in Figure 7c shows slightly inferior optical absorptance than the double layer tandem system. The maximum solar absorptance observed in triple layer system was around 94.4. Moreover, it is observed that the nanoporous absorber layer developed by using optimum process duration of $15 \mathrm{~min}$ with an antireflective layer $\left(1^{\text {st }}\right)$ developed with an optical withdrawal speed of $4 \mathrm{~mm} \mathrm{sec}^{-1}$ shows a higher optical absorptance as compared to other absorber layers generated by other process conditions. 

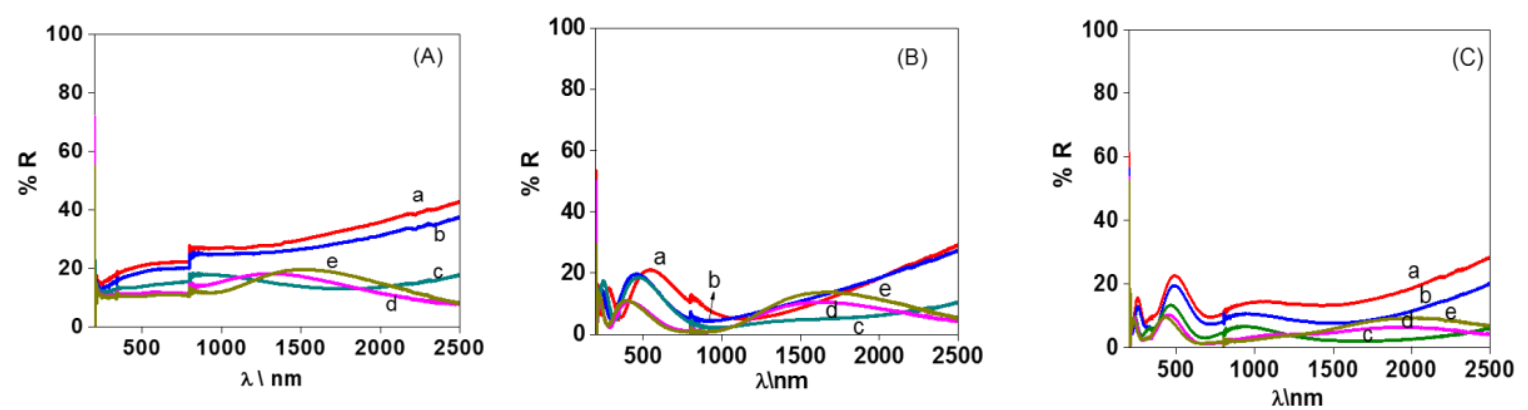

Figure 7. (A) Spectral reflectivity of single absorber layers (nanoporous $\mathrm{Cr}$-Fe-Mn composite oxide) generated by different process durations; a) $9 \mathrm{~min}$, b) $11 \mathrm{~min}$, c) $13 \mathrm{~min}$, d) $15 \mathrm{~min}$ and e) $17 \mathrm{~min}$; (B) double layers absorber tandem (nanoporous $\mathrm{Cr}-\mathrm{Fe}-\mathrm{Mn}$ composite oxide/ $\mathrm{ZrO}_{2}-$ $\mathrm{SiO}_{2}$ ); (C) triple layers absorber tandem (nanoporous $\mathrm{Cr}$-Fe-Mn composite oxide/ $\mathrm{ZrO}_{2}-\mathrm{SiO}_{2} /$ $\mathrm{SiO}_{2}$ ).

Table 2. Solar absorptance data of single absorber layers (nanoporous $\mathrm{Cr}$-Fe-Mn composite oxide); double layers absorber tandem (nanoporous $\mathrm{Cr}-\mathrm{Fe}-\mathrm{Mn}$ composite oxide/ $\mathrm{ZrO}_{2}-\mathrm{SiO}_{2}$ ); (C) triple layers absorber tandem (nanoporous $\mathrm{Cr}$ - $\mathrm{Fe}-\mathrm{Mn}$ composite oxide/ $\mathrm{ZrO}_{2}-\mathrm{SiO}_{2} / \mathrm{SiO}_{2}$ ) generated by varying the process duration.

\begin{tabular}{|c|c|c|c|}
\hline \multirow{2}{*}{$\begin{array}{c}\text { process duration } \\
(\mathrm{min})\end{array}$} & \multicolumn{3}{|c|}{$\alpha(300-2500 \mathrm{~nm})$} \\
\cline { 2 - 4 } & Single & Two layers Tandem & Three layers Tandem \\
\hline 9 & 75.2 & 89.8 & 88.0 \\
\hline 11 & 84.5 & 90.8 & 88.9 \\
\hline 13 & 85.5 & 93.2 & 93.9 \\
\hline 15 & 85.6 & 94.9 & 94.4 \\
\hline 17 & 86.6 & 94.5 & 93.9 \\
\hline
\end{tabular}

\subsection{Thermal emissivity characterization:}

Thermal emissivity characterisation of single nanoporous $\mathrm{Cr}$-Fe-Mn absorber layer generated on SS202 polished substrate by controlled chemical oxidation process using optimum conditions of process duration, process temperature, acid and water ratio and sodium dichromate salt concentration: $15 \mathrm{~min}, 90^{\circ} \mathrm{C}, 3: 5$ and $1 \mathrm{M}$, respectively, double layers absorber tandem (nanoporous $\mathrm{Cr}$-Fe-Mn composite oxide layer $/ \mathrm{ZrO}_{2}-\mathrm{SiO}_{2}$ ) and triple layers absorber tandem ( $\left(\right.$ nanoporous $\mathrm{Cr}$-Fe-Mn composite oxide layer $/ \mathrm{ZrO}_{2}-\mathrm{SiO}_{2} / \mathrm{SiO}_{2}$ nanoparticle layer) exhibit high solar absorptance developed on the polished surface of SS 202 was carried out by FT-IR spectrophotometer using special accessories like a black body furnace 
and high temperature sample cell unit. The thermal emittance of both black body furnace and samples were measured at different temperatures starting from $100^{\circ} \mathrm{C}$ to $300^{\circ} \mathrm{C}$ with an interval of $50^{\circ} \mathrm{C}$. Finally, the thermal emissivity of each sample was calculated from their measured thermal emittance spectrum and black body emittance spectrum using the standard equation as described in literatures [48-50].

Typical thermal emissivity spectra were derived for single and tandem absorber layers from their emittance and black body emittance spectra were recorded at different temperatures from $100-300^{\circ} \mathrm{C}$ and are represented in Fig. 8 and Table. 3. The thermal emissivity of heat radiations from all the layers on SS substrate increases with increasing temperature. Compared to the single nanoporous $\mathrm{Cr}$-Fe-Mn composite oxide absorber layer coated sample, a relatively lower value of thermal emissivity is noted for the double layers absorber tandem due to covering of nanopores in the absorber layer by $\mathrm{ZrO}_{2}-\mathrm{SiO}_{2}$ sol-gel composite layer. Further, it is clearly noted that double layer absorber tandem shows low thermal emissivity value of $0.092-0.122$ from $100^{\circ} \mathrm{C}$ to $300^{\circ} \mathrm{C}$. However, the single nanocomposite absorber layer having nanoporous morphological structure shows a high thermal emissivity range of $0.11-0.144$ measured from $100^{\circ} \mathrm{C}$ to $300^{\circ} \mathrm{C}$. The reason for observing a high thermal emissivity could be presence of pores and voids in the absorber films. The triple layers absorber tandem shows a higher thermal emissivity value of 0.130 0.164 from $100^{\circ} \mathrm{C}$ to $300^{\circ} \mathrm{C}$ when compared to single and double layers absorber tandem. It is due to an addition of porous $\mathrm{SiO}_{2}$ nanoparticle layer in the stack. A high amount of oxide content in the tandem system may cause the high thermal emissivity behaviour. Similar observation has also been observed in our previous work [42] of highly thermally stable $\mathrm{Mn}$ based absorber layer developed by controlled thermal oxidation on a special variety of stainless steel, J4. Similarly, M. Joly et al. have also noted a higher emissivity for their triple layer tandem absorber (graded structure) comprising of $\mathrm{Cu}-\mathrm{Co}-\mathrm{Mn}-\mathrm{O} / \mathrm{Cu}-\mathrm{Co}-\mathrm{Mn}-\mathrm{Si}-$ $\mathrm{O} / \mathrm{SiO}_{\mathrm{x}}$ compared to single, $\mathrm{Cu}-\mathrm{Co}-\mathrm{Mn}-\mathrm{O}$ and double layers tandem, $\mathrm{Cu}-\mathrm{Co}-\mathrm{Mn}-\mathrm{O} / \mathrm{SiO}_{\mathrm{x}}$ [38]. 

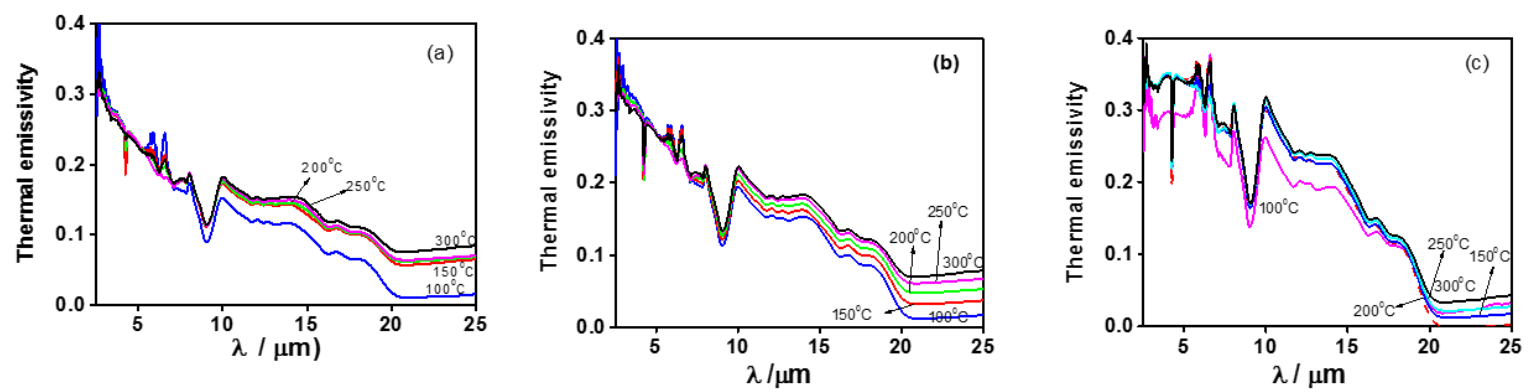

Figure 8. (a) Thermal emissivity spectra of single absorber layer (nanoporous $\mathrm{Cr}$-Fe-Mn composite oxide); (b) double layers absorber tandem (nanoporous $\mathrm{Cr}$ - $\mathrm{Fe}-\mathrm{Mn}$ composite oxide/ $\mathrm{ZrO}_{2}-\mathrm{SiO}_{2}$ ); (c) triple layers absorber tandem (nanoporous $\mathrm{Cr}$ - $\mathrm{Fe}-\mathrm{Mn}$ composite oxide/ $\mathrm{ZrO}_{2}-\mathrm{SiO}_{2} / \mathrm{SiO}_{2}$ ) measured at different temperatures.

Table 3. Thermal emissivity spectra of single absorber layer (nanoporous $\mathrm{Cr}$-Fe-Mn composite oxide), double layers absorber tandem (nanoporous $\mathrm{Cr}$ - $\mathrm{Fe}-\mathrm{Mn}$ composite oxide/ $\mathrm{ZrO}_{2}-\mathrm{SiO}_{2}$ ) and triple layers absorber tandem (nanoporous $\mathrm{Cr}$-Fe-Mn composite oxide/ $\mathrm{ZrO}_{2}$ $\mathrm{SiO}_{2} / \mathrm{SiO}_{2}$ ) measured at different temperatures.

\begin{tabular}{|c|c|c|c|}
\hline \multirow{2}{*}{ Temperature } & \multicolumn{3}{|c|}{$\varepsilon(2.5-25 \mu \mathrm{m})$} \\
\cline { 2 - 4 } & Single layer & Two layer Tandem & Three layer Tandem \\
\hline $100^{\circ} \mathrm{C}$ & 0.110 & 0.092 & 0.130 \\
\hline $150^{\circ} \mathrm{C}$ & 0.135 & 0.108 & 0.144 \\
\hline $200^{\circ} \mathrm{C}$ & 0.137 & 0.114 & 0.151 \\
\hline $250^{\circ} \mathrm{C}$ & 0.138 & 0.116 & 0.158 \\
\hline $300^{\circ} \mathrm{C}$ & 0.144 & 0.122 & 0.164 \\
\hline
\end{tabular}

\subsection{Optical thickness and refractive index results of nanocomposite oxide absorber and antireflective layers:}

The thickness and refractive index of nanoporous $\mathrm{Cr}$-Fe-Mn composite oxide absorber covered with of two antireflective layers i.e. $\mathrm{ZrO}_{2}-\mathrm{SiO}_{2}$ and $\mathrm{SiO}_{2}$ nanoparticle layer, developed by the best optimum conditions were estimated by ellipsometer are represented in Table. 4. The experimental data was fitted with theoretically simulated spectra using a suitable mathematical model for optical constants of the materials. From the fitting, the thicknesses of the layers and the optical constants of the materials was determined similar to our earlier work and a method described elsewhere [42]. The deposited nanoporus 
absorber layer and anti-reflective layers $\left(\mathrm{ZrO}_{2}-\mathrm{SiO}_{2}\right.$ and $\mathrm{SiO}_{2}$ nanoparticle layers) were modelled using the Cauchy dispersion model for generating the refractive indices and extinction coefficient spectra. The thickness and refractive index values of nanoporous $\mathrm{Cr}$ Fe-Mn composite oxide layer are around $108 \pm 5 \mathrm{~nm}$ and $2.04 \pm 0.01,1^{\text {st }}$ antireflective layer $\left(\mathrm{ZrO}_{2}-\mathrm{SiO}_{2}\right): 120 \pm 5 \mathrm{~nm}$ and $1.69 \pm 0.01$, II antireflective layer $\left(\mathrm{SiO}_{2}\right.$ nanoparticle layer $): 160 \pm$ $5 \mathrm{~nm}$ and $1.41 \pm 0.01$, respectively.

Table 4. Summarises the optical property, thickness and refractive index data of nanoporous $\mathrm{Cr}$-Fe-Mn composite oxide (single layer), double layer absorber tandem (nanoporous $\mathrm{Cr}$-Fe$\mathrm{Mn}$ composite oxide/ $\mathrm{ZrO}_{2}-\mathrm{SiO}_{2}$ ) and triple layer absorber tandem (nanoporous $\mathrm{Cr}$-Fe-Mn composite oxide/ $\mathrm{ZrO}_{2}-\mathrm{SiO}_{2} / \mathrm{SiO}_{2}$ )

\begin{tabular}{|l|c|c|c|c|}
\hline \multicolumn{1}{|c|}{ Sample } & $\boldsymbol{\alpha}$ & $\boldsymbol{\varepsilon}_{\mathbf{3 0 0}}{ }^{\mathbf{C}} \mathbf{C}$ & Thickness $(\mathbf{n m})$ & Refractive index \\
\hline Single layer absorber & 85.6 & 0.144 & $108 \pm 5 \mathrm{~nm}$ & $2.04 \pm 0.01$ \\
\hline Double layer absorber tandem & 94.9 & 0.122 & $120 \pm 5 \mathrm{~nm}$ & $1.69 \pm 0.01$ \\
\hline Triple layer absorber tandem & 94.4 & 0.164 & $160 \pm 5 \mathrm{~nm}$ & $1.41 \pm 0.01$ \\
\hline
\end{tabular}

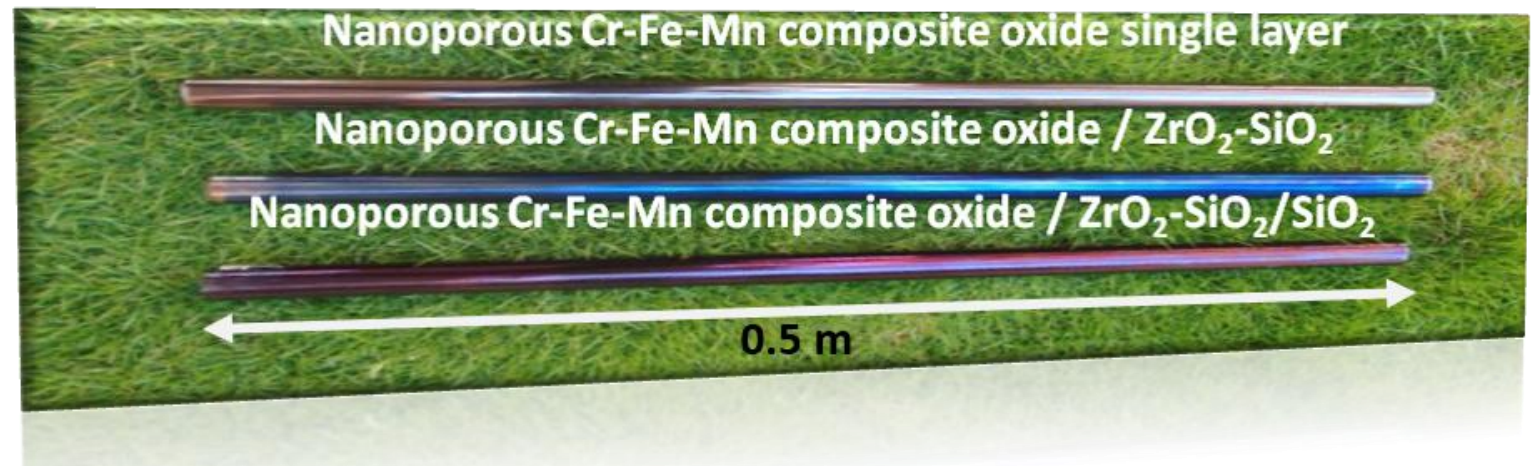

Figure 9. Image of $0.5 \mathrm{~m}$ long of nanoporous Single absorber layer, double and triple layers tandem deposited on 202 SS tubes

\subsection{Corrosion \& thermal stability of nanoporous Cr-Fe-Mn composite oxide absorber and Tandem absorber layer system:}

To understand the corrosion and thermal resistance behaviour of both single and tandem absorber system, the coatings were subjected to a salt spray test for proving the corrosion and weather stability in a salt spray chamber following the ASTM method (ASTM 13117) using $5 \% \mathrm{NaCl}$ solution and generating vapours at a temperature of $35^{\circ} \mathrm{C} / \mathrm{min}$. After every cycle test (24 hours) the coating was inspected for change in properties of solar 
absorptance and thermal emissivity at a maximum temperature of $300^{\circ} \mathrm{C}$ by UV-Vis-NIR and FT-IR spectrophotometer with thermal emissivity accessories. According to the salt spray experiments, the tandem absorber layers (double \& triple layer tandem system) comprising of $\mathrm{ZrO}_{2}-\mathrm{SiO}_{2}$ sol-gel layer for antireflection along with corrosion resistance were found to have no changes in its absorptance and emittance properties even after 200 hours salt spray test (Table 5). However, the sample deposited with only the nanoporous layer could withstand the salt spray test for a maximum of 120 hours only.

Table. 5: Corrosion resistance behaviour of single and tandem absorber system on the solar absorptance and thermal emittance by using salt spray chamber test

\begin{tabular}{|c|c|c|c|c|c|c|}
\hline $\begin{array}{c}\text { Exposed } \\
\text { hours }\end{array}$ & $\begin{array}{c}\boldsymbol{\alpha} \\
\text { single layer } \\
\text { absorber }\end{array}$ & $\begin{array}{c}\text { Double layer } \\
\text { absorber } \\
\text { tandem }\end{array}$ & $\begin{array}{c}\boldsymbol{\alpha} \\
\text { triple layer } \\
\text { absorber } \\
\text { tandem }\end{array}$ & $\begin{array}{c}\boldsymbol{\varepsilon} \mathbf{3 0 0 ^ { 0 } \mathbf { C }} \\
\text { Single layer } \\
\text { absorber }\end{array}$ & $\begin{array}{c}\boldsymbol{\varepsilon}_{\mathbf{3 0 0}}{ }^{\mathbf{C}} \mathbf{c} \\
\text { Double layer } \\
\text { absorber } \\
\text { tandem }\end{array}$ & $\begin{array}{c}\boldsymbol{\varepsilon}_{\mathbf{3 0 0}}{ }^{\mathbf{0}} \mathbf{C} \\
\text { Triple layer } \\
\text { absorber } \\
\text { tandem }\end{array}$ \\
\hline 0 & 85.63 & 94.85 & 94.42 & 0.146 & 0.118 & 0.161 \\
\hline 24 & 84.99 & 94.15 & 93.81 & 0.142 & 0.121 & 0.163 \\
\hline 48 & 84.79 & 93.69 & 93.62 & 0.143 & 0.123 & 0.166 \\
\hline 72 & 84.86 & 93.75 & 93.51 & 0.146 & 0.119 & 0.162 \\
\hline 96 & 84.63 & 93.81 & 93.68 & 0.145 & 0.120 & 0.165 \\
\hline 120 & 84.71 & 93.87 & 93.57 & 0.147 & 0.123 & 0.165 \\
\hline 144 & 83.55 & 93.82 & 93.48 & 0.151 & 0.121 & 0.167 \\
\hline 168 & 83.11 & 93.63 & 93.53 & 0.155 & 0.122 & 0.166 \\
\hline 192 & 82.89 & 93.71 & 93.59 & 0.161 & 0.120 & 0.165 \\
\hline 216 & 82.56 & 93.69 & 93.57 & 0.165 & 0.123 & 0.166 \\
\hline
\end{tabular}

To calculate the thermal stability, the samples were annealed in air at $300^{\circ} \mathrm{C}$ and for a maximum of 100 cycles. Each cycle comprised of $2 \mathrm{~h}$ heating to attain $300^{\circ} \mathrm{C}$, $2 \mathrm{~h}$ soaking duration, and 5-6h cooling to reach the ambient temperature. The dependence of optical properties of the coatings on the thermal treatment was investigated. The solar absorptance and thermal emittance at $300^{\circ} \mathrm{C}$ were measured by UV-Vis-IR and FT-IRSpectrophotometer. According to the experiments, single and tandem absorber layers were found to have no remarkable changes in their absorptance and emittance properties even after 100 cycles (Table 6). However, after $350^{\circ} \mathrm{C}$, the coatings started to degrade and $>10 \%$ of absorptance changes were observed after 10 cycles and no changes were seen in thermal emissivity. 
Table 6 . The effect of thermal resistance behaviour of single and tandem absorber system in air at $300^{\circ} \mathrm{C}$ on the solar absorptance and thermal normal emittance.

\begin{tabular}{|c|c|c|c|c|c|c|}
\hline $\begin{array}{c}\text { No. of } \\
\text { thermal } \\
\text { cycles }\end{array}$ & $\begin{array}{c}\text { Single layer } \\
\text { absorber }\end{array}$ & $\begin{array}{c}\boldsymbol{\alpha} \\
\text { Double layer } \\
\text { absorber } \\
\text { tandem }\end{array}$ & $\begin{array}{c}\mathbf{\alpha} \\
\text { Triple layer } \\
\text { absorber } \\
\text { tandem }\end{array}$ & $\begin{array}{c}\boldsymbol{\varepsilon}_{\mathbf{3 0 0}}{ }^{\mathbf{C}} \mathbf{C} \\
\text { Single layer } \\
\text { absorber }\end{array}$ & $\begin{array}{c}\boldsymbol{\varepsilon}_{\mathbf{3 0 0}{ }^{\mathbf{}} \mathrm{C}} \\
\text { Double layer } \\
\text { absorber } \\
\text { tandem }\end{array}$ & $\begin{array}{c}\boldsymbol{\varepsilon}_{\mathbf{3 0 0}}{ }^{\mathbf{0}} \mathbf{C} \\
\text { Triple layer } \\
\text { absorber } \\
\text { tandem }\end{array}$ \\
\hline 0 & 85.62 & 94.92 & 94.45 & 0.144 & 0.122 & 0.164 \\
\hline 10 & 85.12 & 94.58 & 94.34 & 0.143 & 0.121 & 0.164 \\
\hline 20 & 84.98 & 94.36 & 94.10 & 0.143 & 0.123 & 0.163 \\
\hline 30 & 84.24 & 94.13 & 93.92 & 0.142 & 0.120 & 0.164 \\
\hline 40 & 84.58 & 93.89 & 93.76 & 0.144 & 0.119 & 0.162 \\
\hline 50 & 84.45 & 93.75 & 93.88 & 0.146 & 0.121 & 0.163 \\
\hline 60 & 84.12 & 93.48 & 93.63 & 0.151 & 0.122 & 0.162 \\
\hline 70 & 83.88 & 93.88 & 93.45 & 0.154 & 0.123 & 0.164 \\
\hline 80 & 83.57 & 93.62 & 93.69 & 0.159 & 0.121 & 0.166 \\
\hline 90 & 83.34 & 93.55 & 93.54 & 0.162 & 0.122 & 0.167 \\
\hline 100 & 83.12 & 93.81 & 93.62 & 0.164 & 0.123 & 0.166 \\
\hline
\end{tabular}

\section{Conclusion}

A cost efficient novel tandem absorber design of nanoporous $\mathrm{Cr}$-Fe-Mn composite oxides $/ \mathrm{ZrO}_{2}-\mathrm{SiO}_{2}$ sol-gel composite layer developed on an austenitic stainless steel (SS-202) substrate has been proven to show have excellent optical properties ( $\alpha$ : $94.9 \%$; $\varepsilon_{300^{\circ} \mathrm{C}}$ : 0.122) compared to single and triple layers absorber tandem and single absorber layer along with high corrosion resistance (withstands $>200 \mathrm{~h}$ in salt spray test) and good thermal stability maxium up to $300^{\circ} \mathrm{C}$ in an open air atmosphere. This process of developing receiver tubes is very economical when compared to conventional processes used for developing commercial receiver tubes. Cost of a $4 \mathrm{~m}$ receiver tube developed by the above mentioned process was estimated to be around 30-35 US \$ while commercial tubes available in the market cost approximately 20 to 40 times more. This novel design will allow an increase in the operating temperature in the solar field up to $300^{\circ} \mathrm{C}$, leading to improved performance and reduced cost of ORC based on solar thermal power of generation. 


\section{Acknowledgement}

"This research is based upon work supported by the US-India Partnership to Advance Clean Energy-Research (PACE-R) for the Solar Energy Research Institute for India and the U.S. (SERIIUS) funded jointly by the U.S. Department of Energy subcontract DE AC36-08G028308 (Office of Science, Office of Basic Energy Sciences, and Energy Efficiency and Renewable Energy, Solar Energy Technology Program, with support from the Office of International Affairs) and the Government of India subcontract IUSSTF/JCERDC-SERIIUS/2012 dated 22nd Nov. 2012." Apart from that, the authors also acknowledge Dr. G. Sundararajan, Former Director, Dr. G. Padmanabham, Director i/c, Dr. S.V. Joshi, Former Additional Director and Dr. T.N. Rao, Associate Director of ARCl for their great support for this research. Authors also wish to thank Dr. H. Neha and Mr. M. Ramakrisna for their help in characterizations of coatings by XPS and TEM analysis.

\section{References}

[1] Technology Roadmap; Solar thermal Electricity, International Energy Agency, 2014 Edition, France, 1-42.

[2] Agnihotri, O.P., and Gupta, B. K., Solar Selective Surfaces. 1st ed. Wiley- Interscience Publication, New York, 1981.

[3] Duffie, J. A., Beckman, W.A., Solar Engineering of Thermal Processes. WileyInterscience, New York, 1991.

[4] Gordon, J., Solar Energy, the State of the Art. James \& James, London, 2001.

[5] Kennedy, C.E., Review of Mid- to High-Temperature Solar Selective Absorber Materials. NREL Tech Report, NREL/TP-520-31267, 2002.

[6] S.A.Kalogirou, Solar thermal receivers and applications, Progress in Energy and Combustion Science 30 (2004) 231-295

[7] N. Selvakumar, H.C. Barshilia, Review of physical vapour deposited (PVD) spectrally selective coatings for mid - and high-temperature solar thermal applications, Solar Energy Materials and SolarCells 98(2012)1-23

[8] W. Graf, F. Brucker, M. Köhl, T. Tröscher, V. Wittwer, L. Herlitze, Development of large area sputtered solar absorber coatings, Journal of Non-Crystalline Solids 218 (1997) 380-387

[9] Q. C. Zhang, Stainless-Steel-AIN cermet selective surface deposited by direct current magnetron sputtering technology, Solar Energy Materials and Solar Cells 52 (1998) 95106 
[10] M. Adsten, R. Joerger, K. Järrendahl, E. Wäckelgård, Optical characterization of industrially sputtered nickel-nickel oxide solar selective surface, Solar Energy 68 (2000) 325-328

[11] V. Teixeira, E. Sousa, M. F. Costa, C. Nunes, L. Rosa, M. J. Carvalho, M. Collares- Pereira, E. Roman, J. Gago, Spectrally selective composite coatings of $\mathrm{Cr}-\mathrm{Cr}_{2} \mathrm{O}_{3}$ and $\mathrm{Mo}-\mathrm{Al}_{2} \mathrm{O}_{3}$ for solar energy applications, Thin Solid Films 392 (2001) 320-326.

[12] V. Teixeira*, E. Sousa, M.F. Costaa, C. Nunes, L. Rosa, M.J. Carvalhob, M. CollaresPereira, E. Roman, J. Gago, Chromium-based thin sputtered composite coatings for solar thermal receivers, Vacuum 64 (2002) 299-305.

[13] H.C. Barshilia, N. Selvakumar, K.S. Rajam, A. Biswas, Structure and optical properties of pulsed sputter deposited $\mathrm{Cr}_{x} \mathrm{O}_{y} / \mathrm{Cr} / \mathrm{Cr}_{2} \mathrm{O}_{3}$ solar selective coatings, Journal of Applied Physics 103 (2008) 1-11

[14] H. C. Barshilia, N. Selvakumar, K.S. Rajam, A. Biswas, Optical properties and thermal stability of TiAIN/AION tandem absorber prepared by reactive DC/RF magnetron sputtering, Solar Energy Materials and Solar Cells 92 (2008) 1425-1433.

[15] M. Koželj, A.Š. Vuk, I. Jerman, B. Orel, Corrosion protection of Sunselect, a spectrally selective solar absorber coating, by(3-mercaptopropyl)trimethoxysilane, SolarEnergyMaterials and SolarCells 93 (2009)1733-1742.

[16] Y. Yin, Y. Pan, L.X. Hang, D.R. McKenzie, M.M.M. Bilek, Direct current reactive sputtering $\mathrm{Cr}-\mathrm{Cr}_{2} \mathrm{O}_{3}$ cermet solar selective surfaces for solar hot water applications, Thin Solid Films 517 (2009) 1601-1606

[17] R. Juang, Y. Yeh, B. Chang, W. Chen, T. Chung, Preparation of solar selective absorbing coatings by magnetron sputtering from a single stainless steel target, Thin Solid Films 518 (2010) 5501-5504

[18] Esposito, A. Antonaia, M.L. Addonizio, S.Aprea, Fabrication and optimisation of highly efficient cermet-based spectrally selective coatings for high operating temperature, Thin Solid Films 517(2009)6000-6006

[19] S. Schiller, K.Goedicke, J. Reschke, V. Kirchhoff, S. Schneider, F. Milde, Pulsed magnetron sputtertechnology, Surface and Coatings Technology 61(1993) 331-337

[20] D.Tulchinsky, V. Uvarov, I. Popov, D. Mandler, S. Magdassi, A novel non-selective coating material for solar thermal potential application formed by reaction between sol-gel titania and copper manganese spinel, Solar Energy Materials \& Solar Cells 120 (2014) 23-29.

[21] K. R. Newby, Functional chromium plating, Metal Finishing 97 (1999) 223-247.

[22] V. Moise, R. Cloots, A. Rulmont, Study of the electrochemical synthesis of selective black coatings absorbing solar energy, International Journal of Inorganic Materials 3 (2001) 1323-1329. 
[23] K.D. Lee, Preparation and characterization of black chrome solar selective coatings, Journal of the Korean Physical Society 51(2007)135-144

[24] Z. Zeng, A.Liang, J.Zhang., A review of recent patents on trivalent chromium plating, Recent Patents on Materials Science2 (2009) 50-57

[25] L. Aries, P. Fort, J.A. Flores, J.P. Traverse, Analysis of the conversion coating on Ferric stainless steel of selective absorbers, Solar Energy Materials 14 (1986) 143-159

[26] L. Aries, D. Fraysse, J.P. Traverse, R. Calsou, Growth of selective coating on stainless steel, Thin Solid films 151 (1987) 413-428.

[27] L. Aries, M. El Bakkouri, J.Roy, J.P. Traverse, Thermal oxidation study of thin magnetitebased coating from iron-chromium alloys, Thin solid films 197(1991)143-155.

[28] F.S. Boydag, The optical properties of some steel surfaces with different surface preparations for high temperature use, Solar Energy Materials 13 (1986) 185-195

[29] D.L. Douglass, R.B. Pettit, The selective solar absorptance of in situ-grown oxide films on metals, Solar Energy Materials 4 (1981) 383-402

[30] V. C. Sharma, A. Sharma, P. llenikhena, Chemical oxidation and spectral selectivity of Austenitic stainless steel AISI 321 (For use in solar-Energy Application), Energy 13 (1988) 749-754

[31] C. S. Uma, L.K. Malhotra, K.L. Chopra, Spectrally selective surfaces on stainless steel produced by chemical conversion, Thin solid films 147 (1987) 243-249

[32] T. K. Bostrom, E. Wackelgard, G. Westin, Durability tests of solution-chemically derived spectrally selective absorbers, Solar Energy Materials and Solar Cells 89 (2005) 197-207

[33] G. Katumba, G. Makiwa, T.R. baisitese, L. Olumekor, A. Forbes, E. Wackelgard, Solar selective absorber functionality of carbon nanoparticles embedded in $\mathrm{SiO}_{2}, \mathrm{ZnO}, \mathrm{NiO}$ matrices, Phys. Stat. Sol. (c) 5 (2008), 549-551

[34] T. N. L. Andrea Ambrosini, Chad L. Staiger, Aaron C. Hall, Marlene, Bencomo, Ellen B. Stechel, Improved High Temperature Solar Absorbers for use in Concentrating Solar Power Central Receiver Applications, Sandia National Laboratories, Albuquerque, New Mexico 87185 and Livermore, California 94550, 2010.

[35] J. Vince, A.S. Vuk, U.O. Krasovec, B. Orel, M. Kohl, M.Heck, Solar absorber coatings based on CoCuMnOx spinels prepared via the sol-gel process: structural and optical properties, Solar Energy Materials and Solar Cells 79 (2003) 313-330.

[36] Chao-Ching Chang, Ching-Li Huang, Cheng-Liang Chang, Poly(urethane)-based solar absorber coatings containing nano gold, Solar Energy 91 (2013) 350-357

[37] Amun Amri, XiaoFei Duan, Chun-Yang Yin, Zhong-Tao Jiang, M. Mahbubur Rahman, Solar absorptance of copper-cobalt oxide thin film coatings with nano-size, grain-like 
morphology: Optimization and synchrotron radiation XPS studies, Applied Surface Science 275 (2013) 127- 135

[38] Martin Joly, Yannik Antonetti, Martin Python, Marina Gonzalez, Thomas Gascou, JeanLouis Scartezzini, Andreas Schuler, Novel black selective coating for tubular solar absorbers based on a sol-gel method, Solar Energy 94 (2013) 233-239

[39] S. Sakthivel, V. Premkumar and A. Srinivas Rao "An improved solar selective absorber coating with excellent optical absorptance, low thermal emissivity and excellent corrosion resistance property and a process of producing the same" Indian patent Application no. 1129/DEL/2013.

[40] R. Krechetnikova, G. M. Homsy, Dip coating in the presence of a substrate-liquid interaction potential, PHYSICS OF FLUIDS 17(2005), 102105.

[41] T. Bostrom, E. Wackelgard, G. Westin, Solution-chemical derived nickel-alumina coatings for thermal solar absorbers, Solar Energy 74 (2003) 497-503.

[42] A. Srinivasa Rao and S. Sakthivel, A highly thermally stable Mn-Cu-Fe composite oxide based solar selective absorber layer with low thermal loss at high temperature, Alloys and compounds. 644(2015) 906-9151.

[43] M. Lundh, T. Blom, E. Wackelgard, Antireflection treatment of Thickness Sensitive Spectrally Selective (TSSS) paints for thermal solar absorbers, Solar Energy 84 (2010) 124-129.

[44] B. O. Seraphin, Solar energy conversion: solid state physics aspects, Topics in Applied Physics, vol. 31, Springer, Berlin, 1979, pp. 24-35.

[45] Hsin-Yen Cheng, Jau-Wern Chiou, Jyh-Ming Ting, Yonhua Tzeng, Reactively co-sputter deposited a-C: $\mathrm{H} / \mathrm{Cr}$ thin films: Material characteristics and optical properties, Thin Solid Films 529 (2013) 164-168.

[46] V. Teixeira, E. Sousa, M. F. Costa, C. Nunes, L. Rosa, M. J. Carvalho, M. Collares- Pereira, E. Roman, J. Gago, Spectrally selective composite coatings of $\mathrm{Cr}-\mathrm{Cr}_{2} \mathrm{O}_{3}$ and $\mathrm{Mo}-\mathrm{Al}_{2} \mathrm{O}_{3}$ for solar energy applications, Thin Solid Films 392 (2001) 320-326.

[47] L. Wu, J. Gao, Z. Liu, L. Liang, F. Xia, H. Cao, Thermal aging characteristics of $\mathrm{CrN}_{\mathrm{x}} \mathrm{O}_{\mathrm{y}}$ solar selective absorber coating for flat plate solar thermal collector applications, Solar Energy Materials \& Solar Cells 114 (2013) 186-191.

[48] B. Carlsson, K. Möller, M. Köhl, U. Frei, S. Brunold, Qualification test procedure for solar absorber surface durability, Sol. Energy Mater. Sol. Cells 61 (2000) 255-275.

[49] M.K. Öhl, M. Heck, S. Brunold, U. Frei, B. Carlsson, K.M. Öller, Advanced procedure for the assessment of the life time of solar absorber coatings, Sol. Energy Mater. Sol. Cells 84 (2004) 275-289. 
[50] H. Price, C. Gummo, M.J. Hale, R. Fimbres, R. Mahoney, R. Cipriani, Developments in high-temperature parabolic trough receiver technology, in International Solar Energy Conference, Portland, OR, United States, 11-14 July.2004, article no. 65178, 2004, pp. 659-667. 